\title{
Androstane-3,17-Diol Glucuronide
}

National Cancer Institute

\section{Source}

National Cancer Institute. Androstane-3,17-Diol Glucuronide. NCI Thesaurus. Code C121965.

A glucuronosyltransferase-modified, alcohol-conjugated metabolite of the steroid androsterone and metabolite of the steroid dihydrotestosterone produced in visceral adipose tissue, with weak androg enic activity. Androstane-3,17-diol glucuronide may be used as a marker for peripheral androgen activity. 